\title{
Alleviating Poverty and Hunger in Nigeria: Lessons from the United States of America
}

\author{
By \\ Zakariya D. Goshit \\ Department of History \\ Nasarawa State University, Keffi.
}

\begin{abstract}
:
Nigeria is facing serious poverty and hunger despite her enormous resources. Recent statistics reveal that poverty and hunger are increasing despite successive governments and non-governmental organizations alleviation programmes. Unless, these twin problems are tacked urgently, they are likely to undermine the survival of Nigeria as a nation. In this regard Nigeria can learn from the experience of the United States of America, which has been able to reduce its poverty and hunger to a minimum level.
\end{abstract}

\section{Introduction}

Poverty and hunger are endemic in Nigeria. They have been increasing rather than declining. National Planning Commission (2004) said despite great natural wealth, Nigeria is poor and social development is limited. If present trends continue the country is not likely to meet the Millennium Development Goals. World Bank Reports (1996) on Nigeria observed that:

Nigeria represents a paradox. The country is rich but the people are poor. Nigeria is rich in land, people oil and natural gases...But poverty is pervasive in all regions to different degrees.

In figures, it is reported that the population of Nigerians living below poverty line increased from 27 percent in 1980 to 70 present in 1999 (Vanguard, 1998). This 70 percent lives on less than US $\$ 1$ per day. These poor Nigerians are also inflicted by hunger, which is caused essentially by poverty.

Successive governments in Nigeria have failed to produce enough food to meet the needs of their citizens. Hence food is not only being imported at an exorbitant price, but its shortage has caused hunger, leading to higher cases of malnutrition and Kwashiorkor among its people. Statistics reveal that nearly 40 percent of the children under five years suffer form malnutrition. Today 
many Nigerians cannot eat three square meals daily due to high cost of foodstuffs.

Poverty and hunger are being compounded by other factors such as unemployment, illiteracy, diseases, energy problems, hiving and health problems, debt burden, over population, natural disasters to mention but a few.

Hunger and poverty have become major challenges facing Nigeria and Africa generally. Successive governments, international organizations, such as UNESCO, WHO, UNDP, UNFPA, and Nigerian formed non-government organizations have embarked on various programmes aimed at alleviating hunger and poverty in Nigeria but the problems seem to be defying any solution. Hence its negative social consequences on the masses such as malnutrition, armed robbery, prostitution and child labour.

Nigeria can learn from the experiences of the United States of America which has been relatively successful in fighting hunger and poverty among its citizen.

The purpose of this paper is the examine the causes of poverty and hunger, poverty alleviation programmes and why they have failed in Nigeria. The paper examines how Nigeria can learn from the US. Experience in reducing poverty and hunger among its citizens.

To do this, the paper is divided into the following sub-sections:-

I Review of concepts

II Nature and causes of poverty and hunger in Nigeria.

III Critique of poverty and hunger alleviation programmes in Nigeria.

IV Poverty and Hunger Alleviation Programmes in the U.S.A.

$\mathrm{V} \quad$ Lessons and policy implications for Nigeria

VI Conclusion

\section{Review of Concepts}

There are two key concepts that need to be defined in order to make our discussion clearer, these are "poverty" and "hunger".

Poverty: this is a multidimensional concept that has no acceptable and concise definition. Different people understand it differently. Initially, it was defined in terms of economic factors but overtime other dimensions have been added such as socio-cultural political and basic needs. These have made the definitions richer but longer. For example Olu Ajakaiye states that most economics define poverty simply as a situation of low income or consumption. (Ajakaiye, 1998: 12, 2003). Similarly Eguatu (2002) defines poverty as the inability to meet economic, social and other standards of wellbeing. Poverty therefore to most economists is the inability of living. 
These definitions are however narrow hence some scholars have provided broader definitions of poverty. Olu Ajakaiye once more defines poverty as the inability to meet basic material needs encompassing food, shelter, water, clothing, education, health as well as basic non-material needs including participation, identity, dignity, etc. (Ibid, p. 12). In the same vein, the World Bank defines poverty as unacceptable human deprivation in terms of economic opportunity, education, health and nutrition as well lack of empowerment and security (cited in Abubakar, 2002).

Poverty is usually classified into absolute and relative poverty. Absolute poverty refers to lack of physical minimum requirement for a person or household for existence while relative poverty refers to a person or household whose provision with goods and services is lower than that of other persons (Abubakar, 2003: 102; Eguatu, 2002). From the above, the characteristics of poverty can be summarized to include inadequate resources, nutrition, safe drinking rate, health, education, shelter as well as productive employment.

Hunger: Oxford Advanced Learners Dictionary, Current English, $6^{\text {th }}$ Edition, defines hunger as the state of not having enough food to eat especially when this causes death (synonymous with starvation). Hunger also refers to the chronic malnutrition of hundreds of millions of the poor in the world (Apeldourn 1982:2). Malnutrition causes millions of death every year regardless of whether food markets register shortages or surpluses. Apeldoorn and Watts describe hunger as "silent violence". World Food Council (WFC) in Conference Ottawa in 1979 estimated that 500 millions more were living in precarious conditions (Apeldoorn, 1981).

In Nigeria, Newswatch (1989) reported that malnutrition claimed over 100,000 Nigerian children every year while 60 percent children who are hospitalized suffered from the disease. Hunger thus refers to a state of food insecurity i.e. the inability of people to have access to enough food to maintain a healthy and productive living. Their food intake falls below the internationally acceptable steward of 3500 categories per day.

From the forgoing analysis, poverty and hunger are related terms. Apeldoorn maintains that "silent" famine is poverty problem. Watts (1986) also states that hunger and famine are at the centre of any definition of poverty. Poverty emanates through lack of purchasing power that leads to inadequate food intake and hence widespread malnutrition.

\section{Incidence of Poverty and Hunger in Nigeria.}

Most analysts including government itself accept that hunger and poverty are increasing in Nigeria (Ajakaiye 2003), Abubakar 2003, Federal office 
Statistic, 1996), this can be seen from the period 1980 to 1996. During that period incidence of poverty increased as follows; $27.2 \% 43.3 \%,-42.7 \%$ and 65.5\% for 1980, 1985, 1992, and 1996 respectively (Abubakar, 2003;

Ajakaiye, 2003).

The $27.2 \%$ for 1980 represents a population of $17.7 \%$ million poor persons. By 1996, the population in poverty had dramatically increased to $65.5 \%$ representing $67.1 \%$ million poor persons (Ibid).

Other disturbing features of poverty during this period are the distribution of poverty status. The population of non-poor declined form $73.8 \%$ in 1980 to $34.4 \%$ in 1996 , while the population of moderately poor increased from $21.0 \%$ in 1980 to $36.3 \%$ in 1996 , while those of the core poor increased from $6.2 \%$ in 1980 to $29.3 \%$ in 1996 (Ibid).

With regard to special incidence of poverty, it has remained more sever in the rural areas (Ibid). In 1980 the percentage of poverty was $17.2 \%$ in the urban areas compared to $28.3 \%$ in the rural areas. By 1996 this increased to $58.2 \%$ urban area compared to $69.8 \%$ in the rural areas. In the rural areas the most vulnerable groups are the women and children, who are marginalized from the economic benefits.

Other feature of poverty during this period was increase in infant mortality rate (Abubakar 2002). In 1996 the infant mortality and mortality for children below 5 years were 78 and 147 per 1,000 line births, respectively. These figures are scaring because they were above the average for developing countries, including, even sub-Sahara Africa.

Similarly, there were high prevalence of deadly diseases such as malaria, dipentary, pneumiuia and measles with mortality rate of 919, 386, 146 and 89 per 100,000 respectively, while about $4 \%$ of the population were infected with the HIV virus (ibid). Life expectancy also dropped from 54 years in 1996, while access to potable water, sanitation facilities, communication, adequate shelter, electricity supply, etc were profoundly constrained (Abubakar, 2002 105-106).

It was therefore not unexpected that the Human Development report, 2000 ranked Nigeria number 151 out of 174 countries and among the poorest 20 countries in the world.

\section{Causes of Hunger and Poverty In Nigeria}

Poverty and hunger in Nigeria are caused by several factors. These include the colonial legacies, bad government policies natural disasters, over population, external factors, unemployment, shortage of land, illiteracy, etc. These factors 
cannot be discussed here in detail because they have been discussed elsewhere (Goshit, 2003, 1996). Only some few of them will be discussed briefly.

First, the colonial legacy, (Watts 1983) and Apeldoorn (1981) have discussed in detail how colonialism created poverty and hunger in Nigeria. Colonialism integrated the pre-capitalist economics of Nigeria into world capitalism and made them to produce raw materials for the consumption of European industries as well as made to serve as markets for these manufactured goods. The expansion of commodity production exposed producers to new risks, undermined their food security mechanisms, exploited them, and left them vulnerable to crisis of subsistence (Watts, 1983). Hence, there was a series of famines that inflicted Northern Nigeria during the colonial period.

These policies and crises were inherited by the post-colonial governments, which further worsened the situation through their economic policies. Apeldoorn (1981) described these policies as exported-oriented, motivated not by the dynamics of integrated rural development but rather by external trade and externally urban development. Consequently, the peasant farmers who live in the rural areas and are major food producers in Nigeria, have been marginalized. (Goshit, 2003).

The rise of oil boom in the country in the 1970s led to the neglect of the agricultural sector, thereby leading to decline of food production. By 1975 Nigeria had ceased to be an exporter of cash crops while food import grew from N441,7000,000 in 1976 to N3 billion in 1981. (Watts, 1986).

Mean while petrodollar had created its own problems heightened political expectation, dependent economy, launching of ambitions projects and use of contract awards for execution of projects, leading to rise of social ills (Uguonu (2003). The execution of these projects was done in such a way that the oil boom was siphoned away into individual accounts abroad.

The decline of oil prices at the international market compelled government to cut down on these projects and started to negotiate for loans from the World Bank and International Monetary Fund as from 1980. Consequently, Nigeria started to accumulate foreign debt, whose payment contributed to the decline of the economy.

The introduction of SAP in Nigeria in 1986 by the Babangida government has worsened the situation because of its policy on liberalization, removal of subsidy and devaluation of the naira have raised the cost of living for the urban poor and the rural landless. Reduction in public spending also increased unemployment (West Africa, 1996). The current market driven economic policies have also not helped matters.

IV. Poverty and Hunger Alleviation Programmes in Nigeria 
In order to alleviate poverty and hunger in Nigeria successive governments have adopted various programmes. These include Operation Feed the Nation, River Basin Development Authority, Green Revolution, Agricultural Development Projects, etc.

These projects failed woefully because of marginalization of peasant farmers and corruption (Watts, 1980). Some new ones which were later introduced to cushion the effects of SAP are Directorate of Food, Road, Rural Infrastructure (DFRRI), MAMSER, Better Life for Rural Women, Family Employment Advancement Programme, Nomadic Education, Directorate of Employment, Petroleum Trust Fund and the National Poverty Eradication Programme introduced by the Obasanjo Administration (Uguonu, 2003). NAPEP's goals according to its current Co-ordinator, Dr. Magnus Kpakol are geared towards eradicating extreme poverty, halving the proportion of people living in poverty by 2010 , provide re-orientation and economic empowerment to the poor in Nigeria (Vanguard 2005:22).

Apart from government agencies there are also international organization such as UNICEF, UNDP, UNPFA, FAO, UNESCO, WHO etc. which have set up social intervention strategies to alleviate poverty and hunger in Nigeria (Uguinu: 2003). Other international bodies and non-governmental organizations include Ford Foundation, Mc Arthur Foundation, Carter Foundation, Planned Parenthood Federation of Nigeria, Rotary Club and numerous NGOS formed by Nigerians. In recent years the number of NGOS operating in Nigeria has been increasing.

While these efforts are commendable they have not succeeded in solving poverty and hunger in Nigeria. The worse case is between 2004 and 2005. For example price of one $50 \mathrm{~kg}$ bag of foreign rice increased from N3000 in 2004 to N7,000 in 2005; a bag of maize increased from N5,000 in 2004 to N15,000 in 2005, to mention a few following increase in price of fuel pump in Nigeria from N50 to N65 per litre in 2005 under deregulation programme. Thus, one can correctly describe the year 2005 as the year of high prices of foodstuffs in Nigeria (Fwatshak and Goshit 2005). Unless government listens to the people and changes its policies the hardship as a result of food insecurity is likely to persist for years despite programmes on rice and cassava production, which are mainly for export. Nana - Sinkam (1995) said, "A glaring manifestation of poverty and food insecurity is also the lack of adequate income... particularly so in a situation where the price of basic food commodities tends to be high thus rendering access to food even more problematic".

Several reasons can be advanced to explain failure of poverty and hunger alleviation programmes in Nigeria. Uguono (2003) says these include poor projects management, lack of involvement of common people in planning and 
execution of projects, lack of qualified and committed personnel, inadequate finance, inadequate infrastructure, and endemic corruption by officials. Uguonu (2003:9) further says apart from the above shortcomings in some instances, the intervening organizations focus more on generating revenue from the programme instead of focusing on goal attainment. This attitude is typical of many Nigerian formed NGOS for poverty alleviation. This is mostly done to satisfy personal desires of persons involved in them who see it as mean to personal enrichment.

The results of all these according to Goshit (2003) are increase in cases of malnutrition and Kwashiorkor, continuous importation of foodstuffs, increase in ethnic - religious conflicts and social vices such as armed robbery, prostitution, child labour, corruption to mention just a few.

\section{Poverty and Hunger Alleviation Programmes in the United States of America.}

Before we discuss this in detail, it may be pertinent to examine briefly the nature and growth of the U.S. economy. By any standard the U.S is the richest and largest economy in the whole world. With less than five present of the world's population the U.S. in the early 1990s, produced about 25 present of the worlds output (USIS, 1990,:6). This is more than twice larger than the next largest economy - that is, Japan.

The U.S. economy is a capitalist one. Capitalism is a term used by Karl Marx to describe the control of the factors of production by a small group of capitalists. This is in sharp contrast to a socialist government planning and public ownership of wealth. It does not mean that in the U.S government does not play any role in the economy rather it is mainly that of regulating and guiding. The partnership between the private and government has speeded rapid economic growth in the U.S.

Other factors that have contributed to economic development in the United States include abundant and rich natural resources, rapid population growth, scientific and technological breakthrough, role of entrepreneurs and availability of cheap labour (Cameron, 1989). As a result of industrial revolution by the end of the First World War, the U.S. had become a creditor nation instead of a debtor nation.

Despite this enormous wealth, poverty and hunger persisted among the minorities and recent immigrants in the US. U.S.I.S (1990:2) observed that Americans have been trebled over the years by persistence of poverty in parts 
of their country, despite massive efforts by the federal government and others to eradicate it.

The Department of Labour defines a minimum amount of income necessary for basic maintenance of a family of four. In 1990 a family of four with an annual income below $\$ 13,360$ was classified as being in poverty. The percentage of persons classified as being below poverty dropped from 22. 4 percent in 1959 to 11.4 percent in 1978. In 1989 the percentage of individuals below the poverty was 12.8 . This was due to aggressive war on poverty and hunger by government. Several programmes were adopted to alleviate poverty and hunger in the U.S. These include;

\section{Control and regulation of the economy:-}

This is necessary in areas where private enterprise has been granted a monopoly especially energy and infrastructure. Traditionally, U.S. government was reluctant to intervene in the economy because of the belief in the concept of "Laissez-faire" a doctrine opposing government interference in the economy except where necessary to maintain law and order. (Njoku 2000). Government started to change this attitude in the $19^{\text {th }}$ century when small business, farm and labour movements began asking, government to intervene on their behalf.

To regulate activities of big business Congress Passed several legislations,. These include Inter-Commerce of Act of 1887; Sherman Anti - Trust Act of 1897 and much later Inter -State Commission, the Food and Drug Administration and the Federal Trade Commission. Government involvement is the economy increased considerably in the 1930s as a result of the New Deal (Lawal, 2000). This was introduced by President Franklin D. Roosevelt to alleviate poverty and unemployment following the Great Depression of the 1930s. New Deal expanded government powers in all fields especially banking, agriculture, social security and public welfare. It addressed labour problems, created minimum standards for wages, hours and relief and security.

In adopting the New Deal, President Roosevelt was influenced by the economic ideas of John Maynard Keynes, an English economist who had argued that it was the special duty of government to actively influence the economy through fiscal policies. He asserted that unemployed should be put to work and that incomes should be redistributed so that the poor could have money to spend (USIS, 1990:117)

\section{War on Unemployment}

Keynes' ideas were further put into practice when the congress passed the Employment Act of 1946, which declared that the promotion of 
maximum employment, production and purchasing power was to be the policy of the federal government. Similarly, unemployment insurance scheme was established under the provision of the Social Security Act of 1935. This was federal - state unemployment compensation programme, which was mainly a programme of income support for unemployed U.S. worker. It provides insured wages during times of forced unemployment (USIS, 1990: 185).

\section{Provision of Subsidies to Farmers:-}

Agriculture is very important to the US and government places a lot of attention on it. Government interfered in agriculture by providing aids and subsidizing prices farmers received for their crops (Banwo, 2000). In 1930 farm legislation introduced the concept of a "parity" a price which provided farmers the same relative purchasing power that farmer prices had in a favorable base period (USIS 1990). Under this government bought excess crops above parity price through purchase agreement with farmers.

Government then pays a set of prices to farmers as loans for crops that are placed in storage. Farmer can pay off the loan in full by burning the crops in the stores and by the 1980s government introduced payment - in - kind (PIK) programme. This was aimed at reducing the available stocks of grain, rice, and Cotton, strengthening market prices and lowering government storage costs. Several other subsidies are being enjoyed by American farmers today.

\section{Food - for Peace Program}

Another programme introduced to help dispose of U.S. food surpluses was the Public Law 480 passed by the Congress in 1954 (Apeldorn 1981). US exports of food and fiber had helped promote the recovery of Europe and Japan after World War II. This idea was extended to third world countries on humanitarian grounds. Under this programme much of the food was used as an incentive payment in developing countries where local development projects were paid with America foodstuffs. The programme helped American farmers to get rid of their surplus products, which were depressing prices.

Similar food programmes include free and a reduced prices, school lunches to children of low income families, and distribution of dairy products, cheese, butter and non-fat dry milk to the poor during the 1980 (USIS 1990). Federal food stamp programme is also introduced to enable persons with low income to receive food coupon, which were accepted by food stores as payment for food. Achi and Idu (2003) observed that America upholds that access to nutrition and safe food is the right of every citizen in accordance with the United Nations Stipulation. It was in this regard that President Roosevelt in 1941 announced freedom from want as one of the four freedoms. 


\section{Social Welfare}

Government also supports individuals who can not adequately care for themselves by making grants to low income parents with dependant children, by providing medical care for the aged and indigent, and through social insurance programmes that assist the unemployment and retirees (Fwatshak and Ekpootu, 2003). Government also supplies relief for the poor and help for the disabled. President Lydon B. Johnson launched a war on poverty and succeeded in creating a programme to provide medical assistance to the poor and elderly as well as other initiatives (USIS, 1990: 42). The social security was created in 1935 when President Roosevelt signed the Social Security Act. This programme provides full - rate old age pensions to working people who retire at age 65 , or reduced - rate pensions to those retiring between the ages of 62 and 65. (Fwatshak and Ekpootu 2003). The above are few examples of poverty and hunger alleviation programmes in the US.

This does not mean that poverty and hunger have been eliminated in the US rather they have been reduced to a very low level. Hence the U.S. can afford to send huge food aids to other nations yearly.

\section{Lessons and Policy Implications For Nigeria}

Nigerian can learn a lot from the U.S. experiences, which can go a long way in reducing our poverty and hunger level.

1. The U.S. has reduced its poverty and hunger level because it has worked hard to develop her economy. Unless Nigeria develops her economy it will be difficult to succeed in her fight against hunger and poverty.

2. The U.S. has largely succeeded because of its political stability and consistent policies. Nigeria needs to stabilize her political system and be consistent in her policies rather than every government introducing new programmes.

3. Accountability and transparency have enabled the U.S. to use her resources judiciously. In Nigeria corruption has retarded her progress through diversion of public funds into private pockets. The current war against corruption, which has improved Nigeria's ranking from $2^{\text {nd }}$ to $6^{\text {th }}$ most corruption nation is welcomed.

4. The U.S. has placed much premium on agriculture because of its importance to economic development hence the huge subsidies offered to her farmers. U.S. is therefore the largest food producer in the whole world. Nigerian governments have marginalized the peasant farmers, who produce $70 \%$ of the food in Nigeria. Unless the Nigerian government supports her farmers who 
produces most of our food, poverty and hunger can not be eliminated.

5. The U.S. is deeply committed to the welfare of her citizens and sees freedom from want as a right of all. Hence all poverty alleviation programmes are backed by law. Nigeria should do same to her citizens

\section{Conclusion}

The paper has demonstrated that poverty and hunger are chronic in Nigeria with their negative consequences. Successive governments have adopted several poverty and hunger alleviation programmes but have largely failed because of inconsistent policies, poor funding, poor implementation, corruption, etc. The U.S has succeeded because of its buoyant economy, political stability, consistent economic policies, transparency and account ability, offering direct subsides to farmers and social welfare to the less privileged and backing all programmes by law. Thus, Nigerian can learn much from the U.S. experience in order to reduce poverty and hunger among majority of its population in the $21^{\text {st }}$ century.

\section{References}

- $\quad$ Abubakar, A.G (2003) "Poverty Reduction and Direct Job Creation in Nigeria" in Jega, Attahiru, $M$ and Wakil Haruna (eds),(2003) The Poverty Eradication Programme in Nigeria, Centre for Democratic Research and Training, Mambayya House Bayero University Kano.

- Achi, M. Mgbekem and Idu Ejemot R, (2003) "Adequate Nutrition and Responsible Citizenship: A Reciprocal Formular “ in Shamsudeen O.Amali et al, (eds) Ethnicity, Citizenship and Democracy in the United States of America, ASAN, Ibadan: Humanities Publishers.

- Ajakaiye, Olu (1998), " Conceptualization of Poverty in Nigeria" in proceedings of the Seventh Annual Conference of the Zonal Research Units, Research Department Central Bank of Nigeria, Abuja.

- $\quad$ "Overview of the Current Poverty Eradication Programme In Nigeria", in Jega, Attahiru, M and Wakil Haruna (eds),(2003) The Poverty Eradication Programme in Nigeria, Centre for Democratic Research and Training, Mambayya House Bayero University Kano.

- Apeldoorn, Jan Van (1981) Drought and famine in Nigeria, London: George Allen and Unwirn; 
Banwo, Adeyinka (2000) "Economic Liberalization and Poverty Alleviation: A Comparative Study of the United States of America and Nigeria" in Oyin Ogunba (ed) The Empowerment of the civil Society in a Democracy: Nigeria and the United State of America, ASAN, Ile - Ife, Anchor Print Limited.

- $\quad$ Cameron, Rondo (1989) A Concise Economic History of the World; from Paleolithic times to the present, New York: Oxford University Press.

- Egwuatu, Bertram " Strategies Towards Strengthening the Poverty Eradication Programme in Nigeria" in Jega, Attahiru, M and Wakil Haruna (eds),(2003) The Poverty Eradication Programme in Nigeria, Centre for Democratic Research and Training, Mambayya House Bayero University Kano.

- $\quad$ Falusi, A.O. (1999) "How to Revive Nigerian's Agricultural sector' Guardian Newspapers, May 17

- $\quad$ Federal Office of Statistics, Statistical Analysis of 1996/1997 National Consumer Survey, Poverty Profile for Nigeria 19801996.

- $\quad$ Fwatshak, S.U. and Mfon E. Ekpootu "Political Economy of Freedom From Want: An Assessment Of The Social Security and Welfare Programmes In The United states" (no date, unpublished).

- Fwatshak S.U and Goshit, Zakariya Damina (2005) "The NEPAD and Nigeria's External trade in Agricultural Goods" A paper Presented at the National Conference on the New Partnership for Africa's Development Org. by Inter-gender at Benue State University, Makurdi, $30^{\text {th }}$ Nov.

- Greenwald Douglas and Associates (1965), A Handbook of Terms and organizations, McGraw Hills Incorp, USA.

Goshit, Zakariya Damina, (1996)" The Development of food crisis in the Jos Plateau Area, 1902 - 1999" (Ph. D. Thesis, University of Jos).

(2003) “ The Impact Of The Current Food Crisis on Nigeria" Humanities Review Journal Vol.2. No 2

Imobighe, Thomas A (2004) "Peace and Conflict Resolution in a Democratic Nigeria" in Maduagwu Michael O and Abubakar Sokoto Mohammed (eds) Fulbright Alumni (Nigeria Book of Readings No.2 Challenges and Prospects of Democratization in Nigeria, FAAN NSUKKA, Multi - Educational Services Trust (MEST):

- $\quad$ El-Rufai N.A (2001) "Poverty Alleviation through Economic Democratization" Business Times, Nigeria, June 18-24 
- National Planning Commission Abuja (2004) Meeting Everyone's NEEDS: National Economic Employment and Development Strategy, December, $1^{\text {st }}$.

- $\quad$ Lawal, A. Adebayo (2000) "Management of Poverty and wealth in Nigeria and the United States" in Oyin Ogunba (ed) The Empowerment of the Civil Society in a Democracy: Nigeria and the United State of America, ASAN, Anchor Printer, Ile-Ife.

- Nana - Sinkam S. C. (1995) "Food Self - Sufficiencyas A Strategic option for Africa" in Bade Onimode and Richard Synge (eds) Issues in African Development: Essays in Honour of Adebayo Adedeji at 65, Ijebu - Ode, Heinemann Educational Books (Nigeria) PLC.

- $\quad$ NewsWatch Magazine (1989) Vol. 9. No 11, March 15.

- Njoku, O. N. ( 2000) "Government and Economic Transformation in the $19^{\text {th }}$ century U.S.A.: Thought for Nigeria" in Oyin Oguba (ed) The Empowerment of the civil society of America, Asan; Ile - Ife Ancher Printers.

- $\quad$ Ogar, David Abua (2003) "Alleviating Poverty in a Democratic System: Forestry Approach", Paper presented at the $4^{\text {th }}$ Annual Conference of the Fulbright Alumni Association of Nigeria, National Institute for Policy and Strategic studies, Kuru $30^{\text {th }}$ Nov -3 Dec.

- $\quad$ Ogiji Patricks (2004) The Food Basket Myth: Implication for food Security And Agriculture. Policy Reform in Nigeria, Makurdi, Aboki Publishers.

- $\quad$ Oxford Advanced Learners Dictionary, Current English, $6^{\text {th }}$ Edition, London.

- $\quad$ Uguonu, Chika N (2003) "Poverty, Social Policy and women participation in the Nigerian Democratic process" in Maduagwu Micheal $\mathrm{O}$ and Abubakar Sokoto Mohammed (eds) Fulbright Alumi (Nigeria) Book of readings No 2. Challenges and Prospects of democratization in Nigeria, FAAN, NSUKKA; Multi - Dimensional Published Trust (MEST)

- $\quad$ Vanguard Newspaper (2005) Wed, November 16.

- United States Information Service (1991) An Outline of the American Economy, Washington D.C

- Watts, Michael (1983) Silent Violence: Food, Famine and Peasantry In Northern Nigeria: Berkely University of California (1986) State, oil and Agriculture in Nigeria, Berkely, University of California

West Africa (1996) 8 - 14 July.

- World Bank (1996) Taking Action to Reduce Poverty in SubSaharan Africa: Washington D.C. 